\title{
SEASONAL CHANGES IN SOME COAT TRAITS OF GROWING DROMEDARY CAMELS UNDER EGYPTIAN SEMI-ARID CONDITIONS
}

\author{
E.A. Taha \\ Wool Production and Technology Department, Desert Research Center, Cairo, \\ Egypt
}

\section{SUMMARY}

Coat samples of twelve growing dromedary camels were collected seasonally from the right mid-side to study the effect of the seasonal climatic changes on fiber diameter, staple length, coat depth, fiber length, fiber type ratio and medullation index. The averages of ambient temperature $\left({ }^{\circ} \mathrm{C}\right)$, relative humidity $(\%)$ and total solar radiation $\left(\mathrm{W} / \mathrm{m}^{2}\right)$ were recorded daily and the seasonal averages of these parameters were calculated.

The lowest fiber diameter was observed in winter $(48.5 \pm 0.5 \mu \mathrm{m})$, while the highest was in summer $(63.7 \pm 0.5 \mu \mathrm{m})$. Medullation index followed the same seasonal trend (13.6 \pm 0.9 vs. 19.2 \pm 0.9 , in winter and summer seasons, respectively). In contrast, staple length and coat depth were more in winter $(2.80 \pm 0.05 \mathrm{~cm}$ and $2.38 \pm 0.04 \mathrm{~cm}$, respectively) than in summer $(2.11 \pm 0.053 \mathrm{~cm}$ and $1.86 \pm 0.045 \mathrm{~cm}$, respectively). There was a gradual increase in the percentage of the outer coat fibers from winter $(16.03 \pm 4.28 \%)$ to summer $(37.50 \pm 4.28 \%)$ versus a gradual decrease in the percentage of inner coat fibers $(83.97 \pm 4.28$ to $62.50 \pm 4.28 \%$ in winter and summer, respectively). Ambient temperature correlated $(p<0.01)$ with fiber diameter $(r=0.71)$, coarse fiber percentage $(r=0.47)$ and medullation index $(r=0.54)$. Correlation coefficient between solar radiation and fiber diameter was $(r=0.45$, $p<0.01)$ while that between relative humidity and fiber diameter was $(r=-0.40$, $p<0.01)$.

These results indicate to the conformity between the seasonal climatic changes and camel coat traits to ensure the best adaptation the surrounding environmental condition

Keywords: Fiber diameter, fiber length, medullation, weather

\section{INTRODUCTION}

Camel habitat preference is determined by the climate and nutritional conditions prevailing in a specific area (Heucke et al., 1992). In this context, dromedaries prefer desert conditions which are characterized by a long dry and short rainy season due to their sensitivity to the cold and humid climate as a result of their evolution in the Arabian Peninsula (Bulliet, 1975 and Nowak, 1991). Their well adaptation to their natural habitat stems from their great ability to conserve body water and withstand the fluctuations in ambient temperature between day and night in the open deserts (Schmidt-Nielsen et. al. 1956 and Schmidt-Nielsen 1964).

Issued by The Egyptian Society of Animal Production 
Camel fleece comprises two layers; an outer coat of relatively coarse hair with fiber diameter of 20-120 microns and an inner coat of relatively fine fibers with fiber diameter varying between 19-24 microns which tends to be coarser and sparser in hot climate than in temperate climate (Petrie, 1995). Ansari-Renani (2008) studied the hair follicle cycle of Iranian one-humped camel and indicated that the short fine non medullated fibers (inner coat) are produced from the secondary hair follicles, while the long coarse medullated guard hairs are produced from the primary follicles.

The coat of camel provides protection against the intensive solar radiation and hot climate. It also acts as a barrier against the environmental heat (El-Hassanein, 1989). Guirgis et al. (1992) demonstrated that camel coat shades the skin and body in summer by preventing heat from reaching the skin, and provides insulation in winter. Allaby (2001) reported that the first line of defense the camel has against the environment is its thick fur and skin. The outer layer of fur absorbs heat and prevents it from reaching the skin. The low heat conductivity of camel wool might enhance the protection against heat gain in hot climates and heat loss in cold climates (Mugerwa, 1981 and Al-Ani, 2004).

This study aims to investigate the role body coat of dromedary camel plays in adaptation to surrounding climatic conditions.

\section{MATERIALS AND METHODS}

This study was carried out on twelve growing dromedary camels at Maryout Research Station (35 Km south west of Alexandria) which belongs to Desert Research Center during the period from the first of January to the end of September (2005). Ambient temperature (AT, $\left.{ }^{\circ} \mathrm{C}\right)$, relative humidity $(\mathrm{RH}, \%)$ and total solar radiation $\left(\mathrm{W} / \mathrm{m}^{2}\right)$ were recorded daily during the experimental period by automatic detection computerized unit located in Maryout Research Station.

Animals were fed on a daily ration of $2.5 \mathrm{~kg}$ of concentrates, $1 \mathrm{~kg}$ of Alfa alfa hay and $1 \mathrm{~kg}$ of rice straw (head ${ }^{-1}$ ) in addition to free grazing for 5 hours daily on natural range plants (Atriplex Sp., Kochia indica, and Acacia trees). Fresh water was available twice a day during the experiment period.

Coat samples $\left(10 \times 10 \mathrm{~cm}^{2}\right)$ were clipped from the right side of the body at the end of spring and summer seasons to study the seasonal changes in: fiber thickness, staple length, fiber length, fiber type ratio and medullation index.

Snippets of about $1 \mathrm{~mm}$ length were cut from the staples of each sample at a level of $2 \mathrm{~cm}$ from the base of staple for determination of fiber diameter. These snippets were mounted in liquid paraffin oil and spread on a slide and covered. Not less than 300 snippets were measured using computerized image analyzer (LEICA Q500).

Coat depth was measured by using a millimeter graded ruler placed adjacent to skin in the mid-side position. Length of ten staples from each sample was measured using millimeter ruler according to Booth (1964). The length was obtained without stretching and from the base of the staple to the base of the formed triangle at the tip of the staple. Sub samples not less than 300 fibers were classified into several types according to their coarseness and the percentage of medulla as type A (very coarse fibers with medulla occupying more than $90 \%$ of the fiber), type B (coarse fibers with about $70 \%$ medulla), type C (with about $50 \%$ medulla), type D (with about $30 \%$ medulla) and Fine (non medullated fibers). This classification was considered for 
calculating the medullation index. Percentages of outer and inner coat fibers in each sample were also counted (Guirgis, 1967).

Medullation index (MI) was calculated for each sample, according to the following formula of Pilkington and Purser (1958) and modified by Guirgis (1973)

$$
M I=\frac{1}{10} \sum_{i=1}^{4} P i
$$

Where, $\mathrm{i}=1,2,3$ and 4 are fiber scores for fine, coarse, heterotype and kemp, respectively. $\mathrm{P}_{\mathrm{i}}$ is the percentage of the $\mathrm{i}^{\text {th }}$ class.

Statistical analysis: Data were analyzed using general linear model procedure (GLM) of SAS (2000). The model included the fixed effect of season on the studied traits. Differences between means were tested by Duncan Multiple Range test (Steal and Torrie, 1980). Simple correlation coefficients between the studied coat traits and ambient temperature, relative humidity and total solar radiation were also calculated and tested for significance at $\alpha=0.05$.

Regression coefficients of frequency of categories of fiber diameter on fiber diameter were calculated by using Excel for the three seasons. Where:

The statistical model used was: $Y_{i j}=\mu+S_{i}+e_{i j}$

$\mathrm{Y}_{\mathrm{ij}}=$ the dependent variable under study.

$\mu=$ Overall mean.

$\mathrm{S}_{\mathrm{i}}=$ the effect of $\mathrm{i}^{\text {th }}$ season.

$\mathrm{e}_{\mathrm{ij}}=$ random error.

\section{RESULTS AND DISCUSSION}

The average ambient temperature increased $(\mathrm{P}<0.05)$ from winter to spring $\left(6.8^{\circ} \mathrm{C}\right)$ and from spring to summer $\left(5.7^{\circ} \mathrm{C}\right)$. The average total solar radiation increased $(\mathrm{P}<0.05)$ markedly in spring compared with winter $\left(0.10 \mathrm{~W} / \mathrm{m}^{2}\right)$ while the difference between the averages of spring and summer was minor $\left(0.01 \mathrm{~W} / \mathrm{m}^{2}\right)$. In contrast with those of ambient temperature and total solar radiation, the average relative humidity was higher in winter $(\mathrm{P}<0.05)$ than spring and summer (Table 1$)$.

Table 1. Ambient temperature $\left({ }^{\circ} \mathrm{C}\right)$, total solar radiation $\left(\mathrm{W} / \mathrm{m}^{2}\right)$ and relative humidity (\%) during the different seasons at Maryout Research Station (Mean \pm SD)

\begin{tabular}{llll}
\hline & \multicolumn{1}{c}{ Winter } & \multicolumn{1}{c}{ Spring } & \multicolumn{1}{c}{ Summer } \\
\hline Ambient temperature & $14.82 \pm 2.30^{\mathrm{c}}$ & $21.62 \pm 2.75^{\mathrm{b}}$ & $27.34 \pm 0.76^{\mathrm{a}}$ \\
Total solar radiation & $0.18 \pm 0 . .04^{\mathrm{b}}$ & $0.28 \pm 0.02^{\mathrm{a}}$ & $0.29 \pm 0.03^{\mathrm{a}}$ \\
Relative humidity & $72.43 \pm 2.21^{\mathrm{a}}$ & $71.34 \pm 3.91^{\mathrm{b}}$ & $76.69 \pm 3.06^{\mathrm{b}}$ \\
\hline
\end{tabular}

Values with different superscripts within the same row are significantly different $(\mathrm{p}<0.05)$.

Fiber diameter showed a marked gradual increase from winter to summer (Table 2). The difference between diameter in winter and spring was $4.31 \mu \mathrm{m}$, representing about $8.9 \%$ from the mean obtained in winter. On the other hand, a marked difference was observed between summer and winter $(15.22 \mu \mathrm{m})$, representing about $31.4 \%$. 
Table 2. Least squares means $( \pm$ S.E) of fiber diameter $(\mu \mathrm{m})$, staple length $(\mathrm{cm})$, coat depth $(\mathrm{cm})$ and medullation index of growing camels at different seasons

\begin{tabular}{llll}
\hline Trait & \multicolumn{1}{c}{ Winter } & \multicolumn{1}{c}{ Spring } & \multicolumn{1}{c}{ Summer } \\
\hline Fiber diameter & $48.51 \pm 0.499^{\mathrm{c}}$ & $52.82 \pm 0.499^{\mathrm{b}}$ & $63.73 \pm 0.499^{\mathrm{a}}$ \\
Staple length & $2.80 \pm 0.053^{\mathrm{a}}$ & $2.49 \pm 0.053^{\mathrm{b}}$ & $2.11 \pm 0.053^{\mathrm{c}}$ \\
Coat depth $^{\mathrm{a}}$ & $2.38 \pm 0.045^{\mathrm{a}}$ & $2.12 \pm 0.045^{\mathrm{b}}$ & $1.86 \pm 0.045^{\mathrm{c}}$ \\
Medullation index $^{\mathrm{b}}$ & $13.55 \pm 0.912^{\mathrm{b}}$ & $12.56 \pm 0.912^{\mathrm{b}}$ & $19.22 \pm 0.912^{\mathrm{a}}$ \\
\hline
\end{tabular}

Values with different superscripts within the same row are significantly different $(p<0.05)$.

Figure $1(\mathrm{a}, \mathrm{b}$ and $\mathrm{c})$ illustrates a histogram of fiber diameter frequencies and its cumulative percentages as diagram in the three seasons studied. It could be noticed that fibers with diameter of $\leq 50 \mu \mathrm{m}$ is composed $73 \%, 62 \%$ and $41 \%$ of the coat components in winter, spring and summer, respectively. On the other hand, fibers with diameters $\geq 50 \mu \mathrm{m}$ is composed $27 \%, 38 \%$ and $59 \%$ of the coat components in winter, spring and summer, respectively. The trend lines of fiber diameter categorie frequencies during the three seasons showed that fibers tended to be finer in winter and coarser in summer. The negative regression coefficient of frequency of fiber diameter categories on fiber diameter increased from -116.76 in winter up to -12.262 in summer (Fig. 1). This indicates that the coarse fibers percentages increased with the increase in ambient temperature.

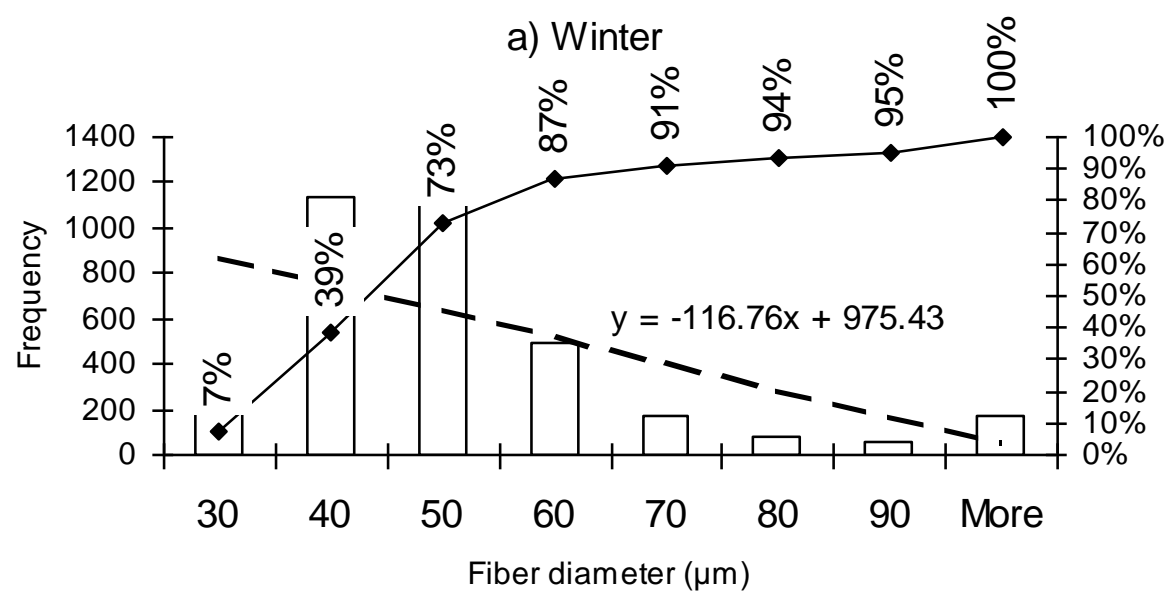

Figure (2) shows a histogram of the percentage of fiber diameter distribution during the different three seasons. It obviously shows that the finer fibers were the dominant coat component during winter while, the coarser fibers were the dominant coat component during summer. 

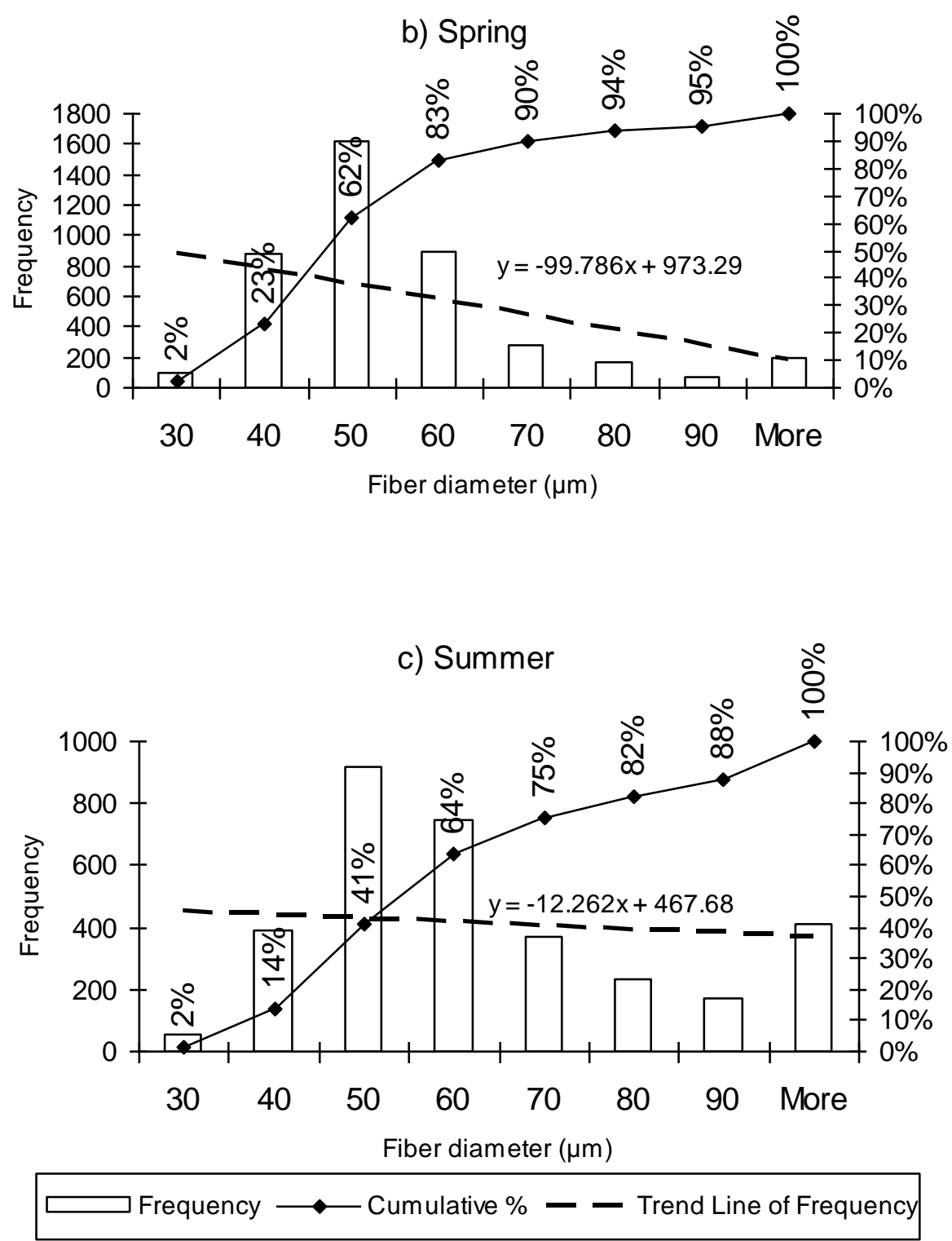

Figure 1. Histogram of fiber diameter category frequency, cumulative percentage and regression line of fiber diameter frequency of camel coat in winter (a), spring (b) and summer (c) seasons

As indicated in Figure (2), it appears that there is a trading off between fine fiber and coarse fiber percentages in winter and summer seasons. Such relationship needs further investigation on larger data set. The average fiber diameter was positively and significantly correlated $(\mathrm{P}<0.01)$ with the ambient temperature $(\mathrm{r}=0.71)$ and solar 
radiation $(\mathrm{r}=0.45)$ (Table 5). However, the correlation coefficient between fiber diameter and relative humidity was negative $(\mathrm{r}=-0.40, \mathrm{P}<0.0 .5)$. The seasonal changes of coat fiber diameter agree with the results of Pertie (1995) who reported that the coats of animals living in hot climates tended to be coarser and sparser. Abdou et al. (2006) reported greater diameter of camel hair in the hot dry season (July) than in the wet season (February) in the extreme south of Egypt. They attributed this difference to the observed increase in the internal diameter of the skin follicles in summer.

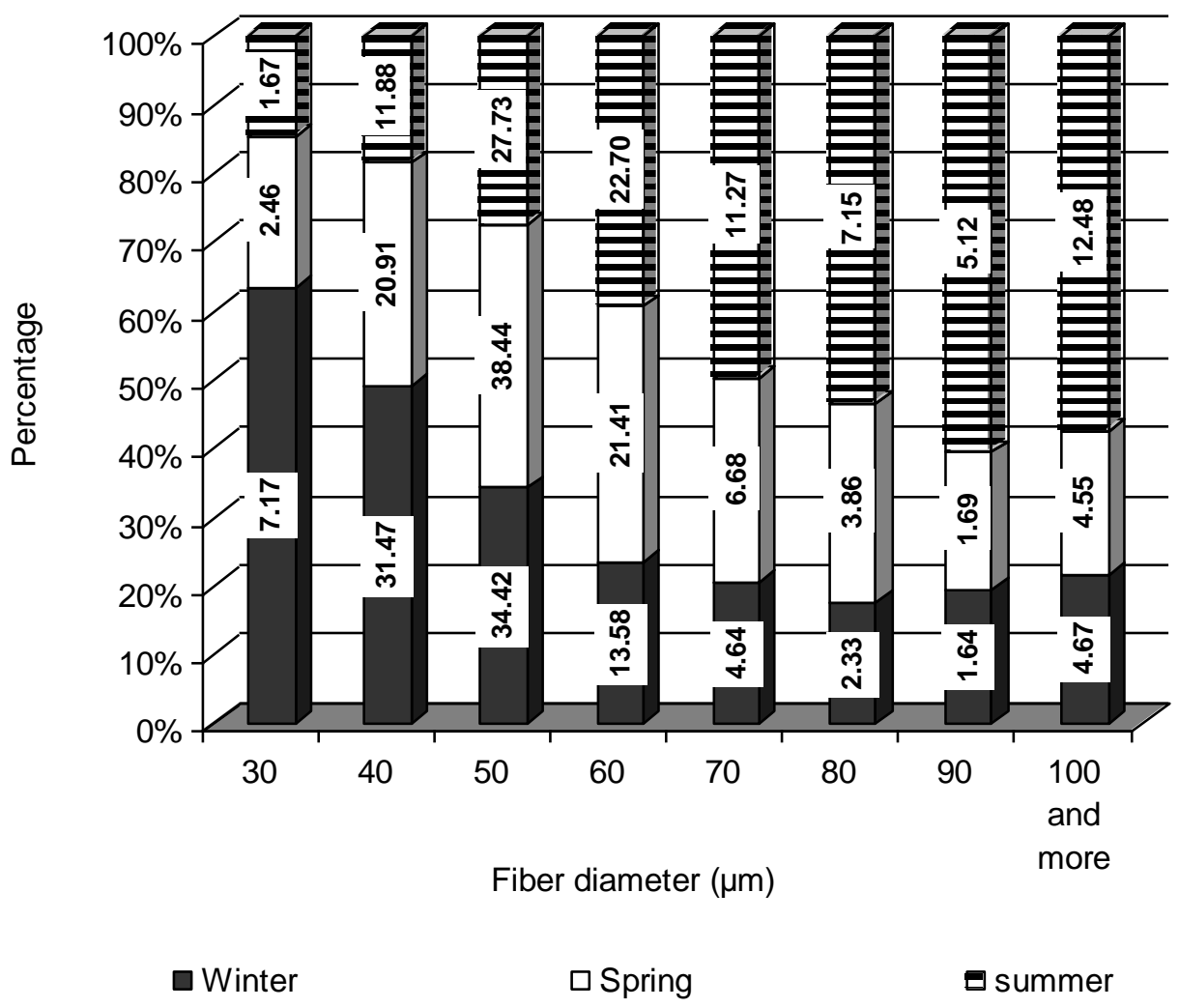

Figure 2. Distribution of fiber diameter percentages of camel coat in winter, spring and summer seasons

Medullation index showed significant $(\mathrm{P}<0.01)$ seasonal fluctuations. It decreased form 13.6 in winter to 12.6 in spring then it markedly increased to 19.22 in summer (Table 2). Correlation coefficient between medullation index and ambient temperature was positive and significant $(\mathrm{r}=0.54, \mathrm{P}<0.01)$ indicating that the increase of medulla could be due to the increase in ambient temperature (Table 5). 
Abundance of medulla increases the protective properties of the fleece by increasing the internal air space (Berger and Mauersberger, 1984). Govindiah and Nagarcenker (1983) indicated that medullated fibers may enhance air movement at the skin surface in summer to provide better heat transmission from skin surface. The observed fluctuation in medullation index may be attributed to the changes in the cycle of follicle activity between seasons (Abdou et. al., 2006 and Ansari-Renani 2008).

Staple length and coat depth showed an opposite trend to that observed for fiber diameter where they tended to decrease from winter to summer (Table 2). The differences among the staple length means were significant $(\mathrm{P}<0.01)$. Bianca $(1968)$ reported that the insulation of the hair coat increases with increasing coat thickness in arctic and tropical species. In cold winter, the increased coat thickness acts to entrap a thicker air layer to decrease the heat dissipation from animal body to the external environment. Whereas in hot summer, animals need to reduce their body insulation to allow more heat dissipation. The thinner coat thickness in summer might allows more air movement at skin surface to increase heat loss by conduction, convection and evaporation and it provides a barrier against the strike of direct sun rays to the skin (Allaby, 2001). Wilson (1984) reported that the natural summer coat of camel decrease water loss by evaporation compared with their shorn counterparts.

Shmidt-Nielson et. al. (1957) reported that camel possesses double layer coat. The fine winter undercoat fibers shed in spring while the thick outer coat remains. In the present study, the percentages of outer and inner coat fibers differ $(\mathrm{P}<0.05)$ seasonally (Table 3 ).

Table 3. Least squares means $( \pm$ S.E) of the percentages of outer and inner coat layers of growing camels in different seasons

\begin{tabular}{lccc}
\hline & Winter & Spring & Summer \\
\hline Outer-coat & $16.03 \pm 4.28^{\mathrm{b}}$ & $11.35 \pm 4.28^{\mathrm{b}}$ & $37.50 \pm 4.28^{\mathrm{a}}$ \\
Inner-coat & $83.97 \pm 4.28^{\mathrm{a}}$ & $88.65 \pm 4.28^{\mathrm{a}}$ & $62.50 \pm 4.28^{\mathrm{b}}$ \\
\hline
\end{tabular}

Values with different superscripts within the same row are significantly different $(\mathrm{P}<0.05)$

In spring, the percentage of outer coat fibers was the lowest, while the percentage of the inner coat was the highest. This may be due to inconsistency between the cycles of primary and secondary follicle activities among seasons. Ansari-Renani (2008) reported that the secondary skin follicles of camel were more susceptible to follicle inactivity than primary follicles. The activity of secondary follicle declined in winter then sharply increased in spring to reach its maxima in summer.

Averages of fiber length of outer and inner coats were higher $(\mathrm{P}<0.05)$ in spring than in winter and summer (Table 4). A positive correlation coefficient ( $r=0.47$, $\mathrm{P}<0.01$ ) was found between the percentage of outer coat fibers and ambient temperature, while the correlation coefficient between the percentage of inner coat fibers and ambient temperature had similar magnitude, but negative ( $r=-0.47$, $\mathrm{P}<0.01$ ) (Table 5).

Table 4. Least squares means $( \pm$ S.E) of fiber length $(\mathrm{cm})$ of growing camels in different seasons

\begin{tabular}{lccc}
\hline & Winter & Spring & Summer \\
\hline Outer-coat $_{\text {Inner-coat }}^{3.87 \pm 0.27^{\mathrm{b}}}$ & $5.06 \pm 0.27^{\mathrm{a}}$ & $2.33 \pm 0.27^{\mathrm{c}}$ \\
\hline & $2.97 \pm 0.27^{\mathrm{a}}$ & $3.11 \pm 0.27^{\mathrm{a}}$ & $2.21 \pm 0.27^{\mathrm{b}}$ \\
\hline
\end{tabular}

Values with different superscripts within the same row are significantly different $(p<0.05)$. 
Table 5. Correlation coefficients between camels coat traits and the meteorological data at different seasons

\begin{tabular}{llll}
\hline & $\begin{array}{c}\text { Ambient } \\
\text { temperature }\end{array}$ & $\begin{array}{c}\text { Solar } \\
\text { radiation }\end{array}$ & $\begin{array}{c}\text { Relative } \\
\text { humidity }\end{array}$ \\
\hline Fiber diameter & $0.71 * *$ & $0.45^{* *}$ & $-0.40^{*}$ \\
Staple length & -0.21 & 0.07 & -0.10 \\
Coat depth & -0.24 & 0.07 & 0.10 \\
Coarse fibers percentage & $0.47 * *$ & 0.16 & 0.11 \\
Fine fibers percentage & $-0.47 * *$ & -0.16 & 0.11 \\
Medullation Index & $0.54 * *$ & 0.20 & -0.15 \\
Average Outer-coat fibers length & -0.16 & 0.14 & -0.18 \\
Average Inner-coat fibers length & -0.38 & 0.15 & 0.12 \\
\hline$* \mathrm{P}<0.05$ ** $\mathrm{P}<0.01$ & & &
\end{tabular}

$* \mathrm{P}<0.05 * * \mathrm{P}<0.01$

Guirgis et. al. (1992) stated that the presence of the inner coat in winter increases the insulating capacity by entrapping a still air layer. The lower dense and shorter fiber length of summer coat might provide suitable conditions to heat acclimatization. According to Bianca (1968) reducing body insulation is one of the main defense methods against heat. Loosing inner coat in hot season reduce the dense of the still air layer and allowing more heat dissipation. Wilson (1984) reported that the coat of desert animals exposed to high temperature and intensive solar radiation should be smooth, reflective and thick enough to act as a barrier against the environmental heat, but not too thick to the extent that reduce evaporative heat loss at the skin surface.

Results of the current study emphasize accommodation of camel coat seasonal changes according to the adaptability requirements of camels to the surrounding environmental conditions.

\section{REFERENCES}

Abdou, A.S.A., Hekal S.A..A. and H. S. Khamis, 2006. Effect of supplementary feeding under different grazing conditions on the skin follicles and hair coat in camels raised at Halaieb, Shalateen and Abo-Ramad triangle, Egypt. Egyptian J. Anim. Prod., 43(2): 139-151.

Al-Ani, F.K., 2004. Camel Management and Diseases. Dar Ammar BookPublisher. Amman, Jordan

Allaby, M., 2001. Deserts. Hong Kong: Facts on File, Inc.

Ansari-Renani , H.R., 2008. Seasonal hair follicle cycle of Camelus dromedaries. Pakistan J. Bio. Sci. 11 (3): 410-415.

Berger, V.W. and R. Mauersberger, 1984. Physical properties of wool. In: American Wool Handbook. Textile Book Publishers Inc., New York. USA.

Bianca, W., 1968. Thermoregulation. In "Adaptation of Domestic Animals. E.S.E. Hafez. (Ed.). Lee and Febiger. Philadelphia. USA.

Booth, J. E., 1964. Principles of Textile Testing. A Heywood Book. London. UK. 
Bulliet, Richard W., 1975. The Camel and the Wheel. Cambridge: Harvard University Press.

El-Hassanein, E.E., 1989. Some ecological and physical parameters relative to adaptation of camels to the Egyptian desert conditions. Ph. D. Thesis, Fac. Sci., Al-Azhar Univ., Cairo, Egypt.

Govindiah, M. G. and R. Nagarcenker, 1983. Seasonal studies on hair coat in Bos taurus x Bos indicus crossbred dairy cattle. J. Agric. Sci., 17: 371-377.

Guirgis, R.A., 1967. Fiber type arrays and kemp succession in sheep. J. Agri. Sci. Camb., 68: 75-85.

Guirgis, R.A., 1973. The study of the variability in some wool traits in a coarse wool breed of sheep. J. Agri. Sci. Camb., 80: 233-238.

Guirgis, R.A., M.M. El-Ganaieny, R.E.E. Khidr, N.A. El-Sayed and S.S. Abou ElEzz, 1992. Camel hair, role in thermoregulation and as a specialty textile fiber. Egyptian J. Anim. Prod. 29 (1): 61-72.

Heucke, J., B. Dorges and H. Klingel, 1992. Ecology of feral camels in central Australia. In: Allen, W.R., Higgins, A.J., Maybew, I.G., Snow, D.H. and Wade, J.F. (Eds). Proc. $1^{\text {st }}$ Inter. Camel Conf. 1992. Feb. 2-6; Dubayy, United Arab Emirates. R and W Publications. UK.

Mugerwa, M., 1981. The Camel (Camelus dromedarius): a Bibliographical Review. International Livestock Center for Africa. Addis Ababa, Ethiopia.

Nowak, R.M., 1991. Walker's Mammals of the World. Vol II. Baltimore: John Hopkins University Press. USA.

Petrie, O.J. 1995. Harvesting of Textile Animal Fibers. FAO Agricultural Service Bulletin NO.122.

Pilkington, J.M. and A.F. Purser, 1958. Lamb survival, growth and fleece production in relation to birth coat type among Welsh Mountain sheep. Anim. Prod., 9: $75-$ 85.

SAS, 2000. Statistical Analysis System. Ver. 8. SAS User Guide, Statistics. Cary, NC. USA.

Schmidt-Nielsen, B.., K. Schmidt-Nielsen, T.R. Houpt and S.A. Jarnus, 1956. Water balance of the camel. Amer. J. Physiol., 185: 185-194.

Schmidt-Nielsen, K., 1964. Desert Animals: Physiological Problems of Heat and Water. Oxford University Press.

Schmidt-Nielsen, K., B. Schmidt-Nielsen, S.S. Jarnum and T.R. Houpt, 1957. Body temperature of the camel and its relation to water economy. Amer. J. Physiol. 188:103-112.

Steal, R.G.D. and J.H. Torrie, 1980. Principals and Procedures of Statistics. A Biometrical Approach. Mac Graw-Hill Com., USA.

Wilson, R.T., 1984. The Camel. Longman, London. UK. 
التغيرات الموسمية في بعض صفات غطاء الجسم في الجمال النامية وحيدة السنام تحت الظروف المصرية الثبه الجافة

عماد الإسلام أحمد طلعت طه

قسم إنتاج و تكنولوجيا الصوف، مركز بحوث الصحراء، القاهة

أجريت هذه الدراسة على با من الجمال النامية وحيدة السنام بمحطة بحوث مريوط التابعة لمركز بحوث

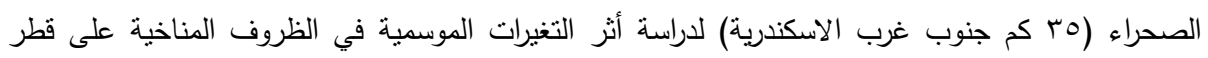

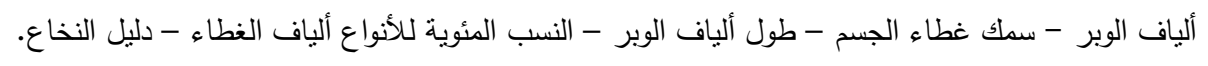

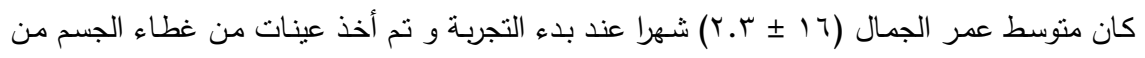

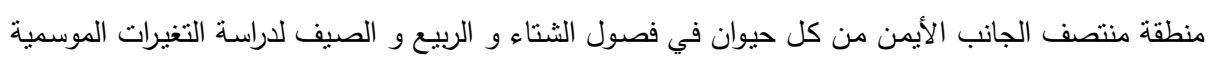

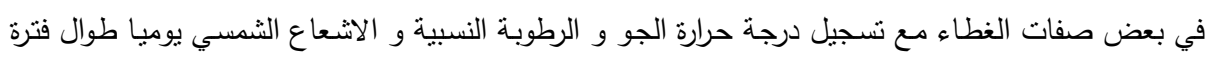

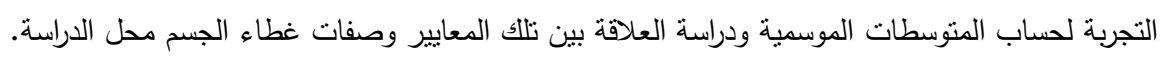

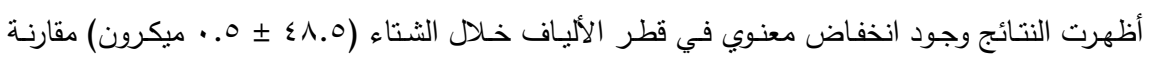

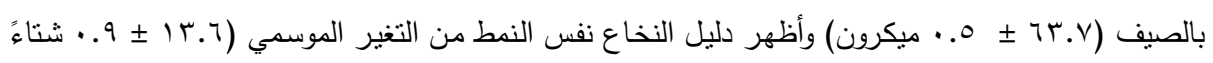

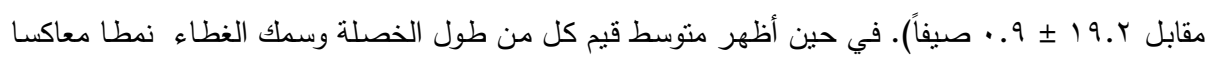

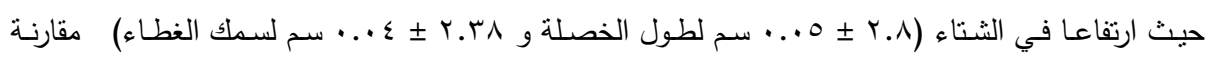

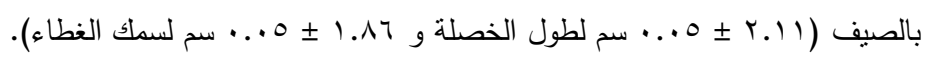

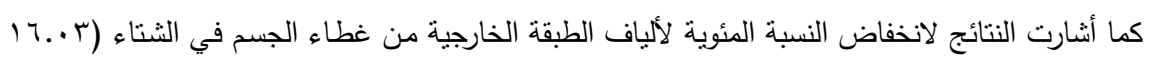

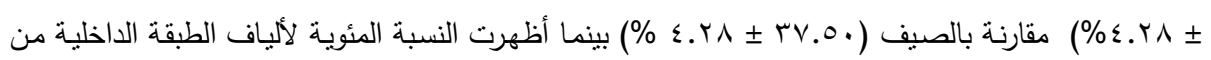

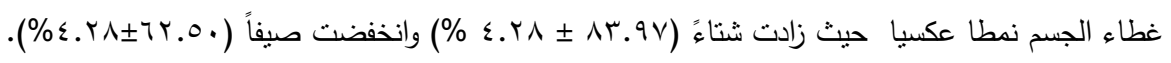

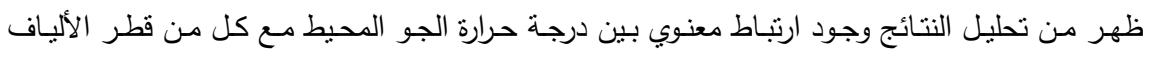

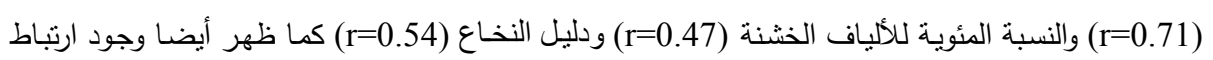

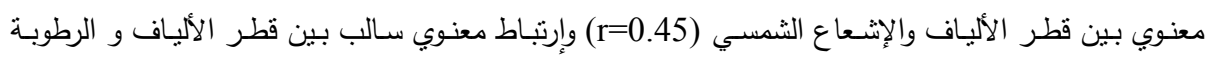

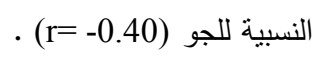

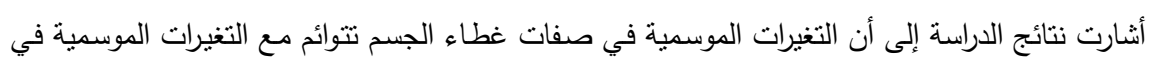
الظروف الجوية المحيطة لتوفير أكبر قدر من التكيف مع البيئة المحيطة. 